\title{
Fundamental Rights and the European Regulation of iConsumer Contracts
}

\author{
Chantal Mak
}

Received: 19 June 2008 / Accepted: 6 November 2008 /

Published online: 21 November 2008

(C) The Author(s) 2008. This article is published with open access at Springerlink.com

\begin{abstract}
This paper addresses the question of how fundamental rights affect European legislation and adjudication on contracts regarding digital information services (iConsumer contracts). Fundamental rights may be seen as representing political choices for the protection of certain values in society, but at the same time, they are enacted rules of the legal system, which may be invoked to enforce the protection of the interests they represent. It is submitted that because of this double-faced nature, they can bring to the fore policy issues in contract legislation and case law. Fundamental rights can thus play a role in evaluating the policy choices that are being made in the review of the acquis communautaire in the field of consumer law. For iConsumer contracts, that means that the rights of consumers, authors, and suppliers of copyright-protected content affect the choice of rule-solutions on the European legislative level. Furthermore, these rights have an impact on the case law of the European Court of Justice in the field of e-commerce. Fundamental rights help define the various rule-solutions the Court can choose from and thus demarcate the law-making capacity of the judiciary.
\end{abstract}

Keywords Consumer law · European Union · Fundamental rights · E-commerce

\section{Introduction}

While not so long ago, music and films could only be obtained by purchasing LPs, CDs, video cassettes, or DVDs, downloading songs and movies from the Internet has by now become common practice. Some artists even adhere to the trend, such as Radiohead, who released their latest album In Rainbows on the web and let their fans decide how much they were willing to pay for downloading it. Nevertheless, the music and movie industry is concerned with the losses suffered as a consequence of the negative effect of (illegal) downloads on record and video sales. The rapidly changing market for music and films

C. Mak $(\bowtie)$

Centre for the Study of European Contract Law, University of Amsterdam, P.O. Box 1030, 1000 BA Amsterdam, the Netherlands

e-mail: c.mak@uva.nl 
poses challenges to copyright and consumer law, which aim to protect the interests of parties involved in digital information services. Not surprisingly, therefore, the growing online supply of and demand for these types of products is one of the concerns of the European Commission in the context of the ongoing review of the European consumer law acquis (Commission 2006). How will a balance be struck between the needs of consumers of copyright protected content (iConsumers) and the copyright holders?

An answer to the question of how policy choices regarding the protection of the iConsumer will turn out may be found by studying a development that is obtaining an equally prominent place in the further harmonisation of European contract law: the impact of fundamental rights on the regulation of (consumer) contracts (see also Mak 2008). The iConsumer, the author, and the supplier/copyright holder of a digital product can all three invoke rights that enjoy the protection of national Constitutions or international human rights treaties. On the consumer's side, these include privacy and the freedom to receive information, while on the author's and supplier's side, one may think of personality rights and the protection of property rights. The European legislature and the European judges have to strike a balance between these rights when formulating specific rules in the area of iConsumer contract law.

This paper addresses the question of how fundamental rights affect European legislation and adjudication concerning iConsumer contracts. It is submitted that fundamental rights argumentation brings into the open the policy questions underlying the regulation of iConsumer relations, which concern the balance between principles of autonomy and solidarity in these contracts. The explicit consideration of the fundamental rights of iConsumers, authors, and suppliers, it is argued, provides the legislature and the judiciary with a framework for making policy choices regarding the regulation of iConsumer contracts. The paper is organised as follows: first, the general relationship between fundamental rights and (consumer) contract law will be looked into, in order to sketch the background against which iConsumer contracts are regulated in Europe. Subsequently, attention will be paid to the impact of several specific fundamental rights on legislative and adjudicative processes, respectively. In conclusion, it may be seen to what extent policy choices in European iConsumer law are affected by fundamental rights argumentation.

\section{Fundamental Rights and European (Consumer) Contract Law}

\section{Historical Development}

The growing success of fundamental rights application in European contract law can partly be explained in the light of the strong general emphasis on entrenchment of these rights in the aftermath of the Second World War. In the early post-war years, initiatives were taken to establish a legal framework that provided sufficient protection against a reoccurrence of the atrocities that had taken place during wartime. On the international level, several important human rights documents were introduced, such as the Universal Declaration of Human Rights (1948), the European Convention for the Protection of Human Rights and Fundamental Freedoms (ECHR 1950), the European Social Charter (1961), the International Covenant on Civil and Political Rights (ICCPR, 1966) and the International Covenant on Economic, Social and Cultural Rights (ICESCR 1966). Moreover, on the national level, a number of fundamental rights were strongly entrenched by the documents constituting the Federal Republic of Germany (the Grundgesetz (GG) of 1949), the Republic of Italy (the Costituzione of 1948), and the Fifth French Republic (the 
Constitution of $1958,{ }^{1}$ which referred to the Preamble to the "social" Constitution of the Fourth French Republic that was founded in 1946). It did not take long for the question to arise as to whether these international and constitutional rights, written for the protection of the citizen against the state, could also affect relations between citizens, in which equally serious infringements of fundamental rights were considered to have taken place.

Many European legal systems provide examples of the manner in which fundamental rights have infiltrated contract law (Brüggemeier et al. 2009a and b; Colombi Ciacchi 2006). German law is probably the most advanced on this topic. It has recognised a reciprocal effect, or Wechselwirkung, of fundamental, constitutional rights and norms of private law since the 1950s. The Bundesverfassungsgericht, the German Federal Constitutional Court, established that all private law should comply with the objective order of values protected by the Constitution. ${ }^{2}$ In case law, this could be realised especially through the interpretation of the general clauses of private law (Wechselwirkung). In the 1990s, the Court extended this doctrine to include the judicial review of the contents of contracts, based on the interpretation of "good morals" and "good faith" in the light of fundamental rights. Thus, a non-competition clause in a commercial agency contract could be contested for its serious restriction of the agent's free choice of profession, ${ }^{3}$ and a surety agreement signed by a non-pecunious daughter on behalf of her father could be annulled with an eye on the protection of human dignity and the principle of the social state. ${ }^{4}$

Italian law, representing a Romanistic perspective, also demonstrates how fundamental rights have affected the development of private law doctrines from the 1950s onwards. The Italian Constitutional Court (Corte costituzionale) and Supreme Court (Corte di Cassazione), after a tentative start, ${ }^{5}$ have established a steady practice of reading provisions of private law in the light of constitutionally protected rights (Busnelli 1991; Chiarella 2004). In contrast to German law, the influence of the Italian Constitutional Court is a more indirect one, given that the Corte costituzionale does not handle individual complaints of unconstitutionality, but adjudicates the compliance of laws with the Constitution in cases that are referred to it by the civil courts. Nevertheless, the judgments of the Corte Costituzionale have had an impact also on certain areas of private law, for instance, on the recognition of non-pecuniary damages. ${ }^{6}$ The Court has developed a method of reading specific provisions of law, mostly general clauses, in the light of constitutionally protected rights, the so-called "combinato disposto" (Morelli 1996, p. 539). In contract law, the Italian Supreme Court has applied this method to the general clause of "good faith," determining that the principle of solidarity, safeguarded by Article 2 of the Costituzione, ${ }^{7}$ requires the civil courts to make sure that contract parties have substantively been able to

\footnotetext{
${ }^{1}$ Only with the Constitution of the Fifth French Republic was constitutional standing given to the Déclaration des droits de l'homme et du citoyen of 1789.

${ }^{2}$ BVerfGE 7, 198 (Lüth).

${ }^{3}$ BVerfGE 81, 242 (Handelsvertreter).

${ }^{4}$ BVerfGE 89, 214 (Bürgschaft).

${ }^{5}$ Early cases go back to the 1950s, for instance, Cass. civ. 10 August 1953, Giust. civ. 1953, 2687. The impact of fundamental rights, however, seems to have expanded mostly from the 1970s and 1980s onwards.

${ }^{6}$ Corte cost. 14 July 1986, n. 184 and Corte cost. 11 July 2003, n. 233. The latter judgment affirms the Italian Supreme Court's decisions Cass. civ. 31 May 2003, n. 8827 and 8828, Foro it. 2003, I, 2273.

${ }^{7}$ Article 2 Cost:: "La Repubblica riconosce e garantisce i diritti inviolabili dell'uomo, sia come singolo sia nelle formazioni sociali ove si svolge la sua personalità, e richiede l'adempimento dei doveri inderogabili di solidarietà politica, economica e sociale."
} 
contribute to the content of their contract. ${ }^{8}$ Furthermore, also on the basis of Article 2 of the Italian Constitution, the Corte di Cassazione has established an ex officio power of the civil court to reduce manifestly excessive contractual penalties. ${ }^{9}$

In European countries that experienced less dramatic post-war constitutional changes, the discourse gathered momentum in a later phase, often inspired by the German cases and the rapidly expanding amount of literature on the topic. In Dutch law, rules similar to the German ones have been developed in case law determining the impact of fundamental rights on the colouring of general clauses of private law. The Dutch Supreme Court, the Hoge Raad, has for instance held that the legality of a contractual waiver of the right to practice the Mensendieck method for improvement of posture should be assessed in light of the fundamental right to teach. ${ }^{10}$ Moreover, the Court has ruled that contractual good faith can set a limit to the right to physical integrity, insofar as it obliges a patient to cooperate to a blood test in order to establish whether his doctor may have been infected with the HIV virus. ${ }^{11}$ Although the Dutch courts tend to lean towards a somewhat less dogmatic approach than their German counterparts, the rules established in these cases resemble the German theory of reciprocal effect or Wechselwirkung between fundamental rights and private law.

In English law, finally, the debate on effects of fundamental rights in contract cases has been rekindled by the Human Rights Act 1998 (HRA), which came into force on 2 October 2000 and aims to give further effect to ECHR rights in British law. Should the Act also apply in relations between private parties? Although legal academics have fervently debated the role of the HRA in private disputes (Bamforth 2001; Beale and Pittam 2001; Beatson and Grosz 2000; Buxton 2000; Cooper 2000; Hunt 1998; Phillipson 1999; Taylor 2002; Wade 1998, 2000), the courts in civil cases have so far not fully dealt with the question of "horizontal effect issues." In some cases, courts have given a certain effect to Convention rights, but rather than elaborating on the role of fundamental rights in the further development of private law, judges tend to bring cases under existing doctrines of private law (Morgan 2004, p. 564; Phillipson 2003a, p. 54 and b, p. 726). The protection of privacy, for example, appears to have been affected by articles 8 and 10 ECHR (respect for privacy and freedom of expression, respectively). ${ }^{12}$ However, instead of considering the duties of the legislature and the judiciary to safeguard these rights in private disputes, the courts have resolved the cases on the basis of an extended interpretation of the doctrine of breach of confidence, which allowed them to remain within the sphere of a balance of private law interests (Phillipson 2003b, p. 731). ${ }^{13}$ In contract law, examples are even fewer, ${ }^{14}$ which means that it remains unclear what is or will be the role of fundamental rights in English contract law adjudication. Although the courts have affirmed that one

\footnotetext{
${ }^{8}$ Cass. civ. 20 April 1994, n. 3775, Giust. civ. 1994, pp. 2159-2173.

${ }^{9}$ Cass. civ. 24 September 1999, n. 10511, Foro it. 2000, I, 1929; Cass. civ., joint divisions, 13 September 2005, n. 18128, Foro it. 2005, I, 2985; Cass. civ. 28 September 2006, n. 21066.

${ }^{10}$ NJ 1970, 57 (Mensendieck I) and NJ 1971, 407 (Mensendieck II).

${ }^{11}$ NJ 2004, 117 (HIV test II or dentist case). See also NJ 1994, 347 (Aids test or HIV test I), in which it was accepted that the right to physical integrity may be restricted in case the person invoking it is himself liable in tort towards the person requiring his cooperation to the blood test.

${ }^{12}$ Campbell v. MGN [2002] EWCA Civ 1373; [2004] UKHL 22; [2004] 2 AC 457 (HL); and Douglas v. Hello! Ltd [2001] QB 967; [2001] 2 WLR 992; [2003] EMLR 31; [2006] QB 125.

13 "[T] $[$ here remains in the judgments a noticeable tendency to gravitate back towards confidentiality principles, even as the new role of Article 8 is apparently accepted: this results in a certain equivocation in the judgments as between the values of confidentiality on the one hand, and privacy on the other."

14 Wilson v. First County Trust Ltd [2003] UKHL 40; [2003] 3 WLR 568; [2003] 4 All ER 97; [2003] 2 All ER (Comm) 491; [2003] HRLR 33.
} 
private party cannot directly sue another private party for a tort of "breach of the Convention," they have only partly clarified to what extent the indirect application of the ECHR rights may affect the balance of interests in contractual disputes (Mak 2008, pp. 143-145; Wadham et al. 2007, pp. 68-69, with references).

\section{The Intermediary Role of Fundamental Rights in Contract Law}

The questions raised in case law have often been analysed in terms of direct and indirect effects of fundamental rights. A direct effect implies that a fundamental right is applied to a case between private parties in the same way as it would be applied to a case involving the State (Barak 2001). Indeed, it is held that fundamental rights may be infringed by private parties in a similar way as by the State and should therefore be given effect in contract law as in public law. The theory of indirect effect rejects this view, arguing that private parties in principle are not addressees of fundamental rights and cannot be requested to take into account matters of public interest in their interprivate relations (Barak 2001, with further references). Fundamental rights, from that perspective, can at most serve as an inspiration for the solution of contractual disputes in which values protected by these rights are at stake. Case solutions should, however, always be embedded in norms of contract law.

It seems that a systematisation of case law according to the distinction between direct and indirect effects cannot fully explain the role of fundamental rights in European contract law (Mak 2008, Chapter 3). Even though a differentiation may be made between forms of direct and indirect effects, these do not prescribe the manner in which judges should handle fundamental rights arguments in specific cases. In particular, the theoretical framework does not provide clear guidelines for establishing the intensity of the impact of these rights. The reason for the fact that the direct/indirect effects distinction cannot clarify the relationship between constitutional law and contract law, it is submitted, is that it is defined by this relationship itself: someone who considers constitutional law to be superior to contract law will favour a direct effect of fundamental rights, whereas someone who seeks to preserve the autonomous nature of contract law will prefer an indirect manner of giving effect to these rights. Trying to distil more general rules on the application of fundamental rights in contract cases from the specific case examples showing these varying effects thus unintentionally brings to mind Baron von Münchhausen pulling himself out of the swamp.

In order to overcome this impasse, the legal-political aspects of the topic may be explored. Often, it seems that judges in civil cases balance interests rather than rights of the parties, and consequently, the values and interests protected by fundamental rights are included in this process. An essential difference between interests secured by fundamental rights and interests safeguarded through private law rules and principles, however, is that the former bear a relation which is much closer to issues of public policy than the latter. After all, they represent the views of society on values that are so fundamental that they should be guaranteed on all levels of public law as well as private law. From this presumption, it follows that the intensity of the impact of fundamental rights in contract law depends on considerations of a legal-political nature.

Regarding the role of fundamental rights in contract law adjudication, it is submitted that these rights can clarify what is actually happening in the adjudicative process. Fundamental rights may be seen as representing political choices for the protection of certain values in society, but at the same time, they are enacted rules of the legal system, which may be invoked to enforce the protection of the interests they represent (Kennedy 1997, p. 308). As such, they mediate in the dichotomy of politics and law. In public law cases, this is apparent from the arguments of both principle (protecting the rights of the citizen against the State, 
for example, freedom of expression) and policy (protecting the interest of society as a whole, for instance, regarding the assurance of free speech) that these rights introduce. In contract law, given the emphasis on interests rather than rights, the distinction between arguments of principle and policy (Dworkin 1977, pp. 82-84) seems to dissolve when fundamental rights are invoked: although the fundamental rights of the parties are explicitly named, the fact that both parties can invoke these rights often results in a balance of the underlying interests rather than a straightforward enforcement of the parties' rights. Given that both lines of argument based on principle and lines of argument based on policy may be open to political influences (Kennedy 1997 and 2002), the application of fundamental rights can reveal the political stakes involved in contract cases.

Fundamental rights thus place the legal question in a broader context, considering the possible solutions of a case in terms of the policy choices they imply (Kennedy 2002, p. 7; Hesselink 2001, pp. 48-52). Generally speaking, such policy choices range from the optimisation of the market to the protection of weaker contracting parties (Kennedy 1976, p. 1685). The legislature should take into account fundamental rights when striking a balance in abstracto, whereas the judge may refer to these rights in order to resolve a case in concreto (Mak 2007, p. 67). The choice between the various policy goals is of particular importance for consumer contracts, where an emphasis on party autonomy competes with the development of the European internal market through consumer protective measures.

\section{Legislating iConsumer Contracts}

\section{European Consumer Law Reviewed}

The European legislature has for some time taken to heart the position of consumers on the European internal market. "Consumer," in this context, in principle refers to natural persons acting for purposes outside their profession, although some have argued that the definition should include persons buying goods that are to be used both for private and business purposes (Loos 2008, pp. 10-12). A number of measures have been enacted that aim to protect consumer interests, such as Directives 93/13/EEC (unfair contract terms) and 99/44/ EC (consumer sales and guarantees). With regard to iConsumer and other distant sales contracts, special provisions can be found in Directives 97/7/EC (distance selling) and 2000/31 (e-commerce).

Eight consumer law Directives ${ }^{15}$ were prominently included in the European Commission's initiatives towards the development of a more coherent European Contract Law (Commission 2001, 2003 and 2004). Part of the Commission's plans was the review of the acquis communautaire in the field of contract law. The evaluation of the consumer acquis was prioritised in the form of a review of eight of the existing consumer law Directives (Green Paper, Commission 2006; Loos 2008). It had to be assessed how these Directives contributed to the "enhancement of consumer and business confidence in the internal market by way of a common high level of consumer protection and by eliminating barriers to the internal market and simplifying legislation" (Loos 2008, pp. 6-7, with further references). The responses to the Commission's Green Paper gave an indication of the

\footnotetext{
${ }^{15}$ Directives 85/577/EEC (doorstep selling), 90/314/EEC (package travel), 93/13/EEC (unfair contract terms), 94/47/EC (timeshare), 97/7/EC (distance selling), 98/6/EC (price indication), 98/27/EC (injunctions for the protection of consumers' interests), and 99/44/EC (consumer sales and guarantees).
} 
opinions of consumer organisations, industry, and academics on the proposed review (Commission Report 2007).

The review process has recently resulted in a proposal by the European Commission for a Directive on Consumer Rights (hereafter: Draft Directive), which aims to revise four of the aforementioned Directives, namely, those on doorstep selling, unfair contract terms, distance contracts, and consumer sales and guarantees (Commission Proposal 2008). Importantly, this proposal does not follow the minimum harmonisation approach of those Directives, which allowed Member States to have stricter national rules than the ones laid down in the Directives. Instead, it proposes a full harmonisation approach, under which Member States will no longer be free to maintain or adopt provisions diverging from the Directives.

The review of the European consumer law acquis has important implications for contracts concerning digital information services (Commission 2006, p. 3). The right of consumers to make private copies of copyright-protected content, for instance, now is on the agenda (Helberger and Hugenholtz 2007). Furthermore, it is the subject of debate whether the protection offered by certain Directives on consumer sales of goods should be extended to other types of contracts, such as those concerning digital information services (Commission 2006, p. 24).

The review of the Directives, it may be submitted, involves the making of policy choices regarding the level of protection that is offered to consumers (compare Van Zelst 2008, Chapter 6). The Commission aims at a further harmonisation of European consumer law, seeing that the current practice of minimum harmonisation has resulted in different levels of consumer protection in the EU Member States (Commission 2006, p. 11). In particular, the Commission intends to give uniform definitions of such terms as "consumer," "professional," "trader," and "right of withdrawal" (Commission 2006, p. 15 ff.; Article 2 of the Draft Directive). Moreover, it has addressed the possible need for the enactment of general rules of contract law and the introduction of a "general principle of good faith and fair dealing" as a means of filling in gaps in consumer protection (Commission 2006, pp. 1112). The regulation of these issues determines to what extent European consumer law, including iConsumer contracts, will emphasise either party autonomy or the protection of weaker contract parties (Collins 2007; Helberger and Hugenholtz 2007, pp. 1080-1084; Mak 2008, Chapter 4).

\section{The Impact of iConsumer Rights on the Legislative Process}

While European integration has traditionally focussed on economic development and the facilitation of cross-border trade, the Commission's initiatives in the area of contract law have sparked debate on the role of social justice in the harmonisation process. The Social Justice Group submits that the European Commission in its Action Plan on European contract law (Commission 2003) appears to overlook this political side of the work on European Contract Law (Social Justice Group 2004). A technocratic approach has been adopted, emphasising the completion of the internal market by removing impediments to cross-border trade. According to the Social Justice Group, the Commission thus avoids the "real issues" engaged by proposals for the harmonisation of contract law in Europe. These real issues are summarised in two starting points, stressing respectively: (a) the "political goal of the construction of a union of shared fundamental values concerning the social and economic relations between citizens"; and (b) the new methods that are needed for the construction of this union of shared fundamental values as represented in contract law and the remainder of private law (Social Justice Group 2004, p. 657). The Manifesto thus forms 
an expression of the growing attention in European legal doctrine for the political issues involved in the harmonisation of contract law (see also Hesselink 2006). Whereas private law, and in particular contract law, is often considered an autonomous field, in which freedom of contract is a main principle, awareness is increasing that the rules of private law may also have effects on the distribution of welfare in society.

From a broader perspective, the politics of European contract law relate to the so-called "constitutionalisation" of European private law (Collins 2007; Social Justice Group 2004, pp. 667-668). As was described in the "Fundamental Rights and European (Consumer) Contract Law" section of this paper, a tendency is emerging in contract law adjudication in various European countries to consider disputes between private parties in the light of fundamental rights. This development starts from the assumption that the rules of private law should comply with the values of the constitutional order (Gerstenberg 2004, p. 766; Smits 2003, pp. 119-120). The judges verify whether the contract respects fundamental values and, indirectly, assess the constitutionality of the relevant rules. For European Contract Law, this means that Directives should respect the rights that form part of the "constitutional traditions common to the Member States" and of "international treaties for the protection of human rights on which the Member States have collaborated or to which they are signatories. ${ }^{16}$ In this context, the European Convention on Human Rights (ECHR) is of particular importance (Art. 6 EU Treaty). ${ }^{17}$ The European courts should make sure that these rights are complied with in specific cases.

With regards to iConsumer contracts, legislation should, in principle, take into account several fundamental rights of the parties involved: the consumer, the author, and the supplier/ copyright holder of digital information services. The iConsumer may refer to such rights as privacy (Art. 8 ECHR), non-discrimination (Art. 14 ECHR) and, possibly, freedom to receive information (Art. 11(1) of the Charter of Fundamental Rights of the EU). The author of a copyright protected work may invoke (unwritten) personality rights. Finally, the supplier/ copyright holder - who in some cases is the same as the author - may rely on the right to enjoy one's property (Art. 1 of the 1st Protocol to the ECHR) to protect his investment in the online services. It is for the European legislature to determine on which rights emphasis will lie in the reviewed consumer acquis.

The responses to the Commission's 2006 Green Paper and of course the Draft Directive on Consumer Rights give insights in the direction the policy-making process will eventually take (Commission Report 2007; Loos 2008, sections 4 ff.). Two examples are singled out here, in order to give an idea of the prevailing tendencies. In the first place, it was suggested to expand the scope of the Consumer Sales Directive to digital content services, software, and data (Commission 2006, p. 24). This proposal found support from consumer organisations and academics, as well as from 18 Member States, who underlined the importance of iConsumer protection (Commission Report 2007, p. 11; Loos 2008, pp. 37-39). The software industry, on the other hand, expressed doubts as to the application of the consumer sales rules to software contracts: the requirement of conformity of goods to the contract (Art. 2 of the Consumer Sales Directive) is difficult to meet in the case of software products. These products by their nature can never be "bug-free," and their functioning depends on the interaction with the computer and with other software applications (Commission Report 2007, p. 11). As a result, consumers may easily claim that the products do not comply with their expectations (non-conformity) and refer to the

\footnotetext{
${ }^{16}$ Case 4/73 Nold v Commission [1974] ECR 491; case 46/87 Hoechst [1989] ECR 2859.

${ }^{17}$ Case 94/00 Roquette Frères SA v Directeur général de la concurrence, de la consommation et de la répression des fraudes [2002] ECR I-9011.
} 
remedies provided in the Consumer Sales Directive (Arts. 3 and 4 of the Directive). This would not be in the interest of the suppliers of software products. As could be expected, the industry thus emphasised party autonomy and individual responsibility, whereas consumer organisations and other actors promoted a more protective regime.

The Commission's Draft Directive does not take a clear stand on the question whether digital content services, software, and date fall within the scope of "goods" and "services" defined by Articles 2(4) and (5). Arguably, software products distributed on tangible devices such as CDs or DVDs might be considered to qualify as "goods," whereas digital content distributed through the Internet might fall within the definition of "services." However, further research in this area and possibly ECJ intervention should still be awaited in order to obtain certainty on this topic (Commission Report 2007, p. 3; Loos 2008, p. 39).

A second example concerns the right of withdrawal granted by the Distance Selling Directive (Art. 6, granting the consumer a right to withdraw from the contract within a period of seven working days, without having to give a reason for the withdrawal). Consumer organisations argued in favour of an expansion of the scope of the Directive and of a reduction of the number of exceptions to the right of withdrawal (Commission Report 2007, pp. 8-9). ${ }^{18}$ Business representatives, on the other hand, pleaded for a reduction of the scope of the Directive or at least of the right of withdrawal (Commission Report 2007, pp. 8-9; Loos 2008, p. 44). The Draft Directive seems to opt for a compromise, giving a withdrawal period of 14 days for distance contracts (Article 12(1) of the Commission's proposal). While businesses will consider this period as too long, consumer organisations will probably still find it too short for consumers to fully assess more complex contracts, such as timeshare agreements. Again, a tension between party autonomy and weaker party protection is felt.

The role of fundamental rights in the choices the European legislature will eventually make lies in the fact that these rights provide a yardstick for assessing the various proposed solutions for iConsumer contracts. A reduction of the scope of the Directives, as supported by the industry, gives prevalence to the author's personality rights and the supplier's property rights. This seems to imply a relatively greater emphasis on party autonomy than on weaker party protection, since the rules of general contract law will prevail over specific consumer-protective measures.

An expansion of the scope of the Directives, on the other hand, wished for by consumer organisations and most academic respondents to the Green Paper, rather favours the iConsumer's freedom to receive information, rights to privacy and non-discrimination, thus opting for a further protection of the weaker contracting party. If the conformity test of the Consumer Sales Directive is eventually expanded to include copyright-protected material, iConsumers may for instance assert that the making of private copies falls within the scope of "normal use" of a product and that they may therefore reasonably expect to be able to make such copies. This would give them a stronger bargaining position in their relations to authors and suppliers than if copyright law alone applied (compare Helberger and Hugenholtz 2007, pp. 1085-1086). Furthermore, application of the principle of nondiscrimination that is part of the consumer acquis would in principle impede suppliers in distinguishing between iConsumers when it comes to giving them access to digital information services.

Still, even though legislation may provide a framework for advancing the aforementioned goals of social justice, it is only through the adequate enforcement of the rules that

${ }^{18}$ In this context, it is worth noticing that several of these exceptions also cover information services (Article 6(3) of the Directive). 
policy aims can truly be achieved. As we shall see in the following section, fundamental rights argumentation is also important in this field: it can make explicit the policy questions underlying iConsumer disputes and thus build a bridge between individual, subjective interests of contract parties and objective goals of society.

\section{Adjudicating iConsumer Contracts}

\section{Judicial Policy Making}

Even if the legislature designs the playing field, it still is up to the judiciary to apply the rules of the game. This means that fundamental rights can only be fully guaranteed through the judicial evaluation of compliance with these rights in the specific case. At the same time, however, the judge's application of fundamental rights may imply further policy choices, insofar as either (1) no answer to the case at hand is available in legislation, or (2) the compliance of legislation with fundamental rights is put into question (Mak 2007, pp. 67-68). ${ }^{19}$

Within the EU, the domestic courts of the Member States have developed various ways of integrating fundamental rights argumentation into their reasoning in contractual disputes. As we have seen in the "Fundamental Rights and European (Consumer) Contract Law" section above, fundamental rights application may induce judges to more explicitly discuss the policy stakes in (consumer) contract cases. This could result in judicial policy making, insofar as the courts develop new lines of case law that "fill gaps" or that deviate from existing legislation.

In the field of iConsumer law, an extra dimension is added by the fact that national legislation on e-commerce has been profoundly affected by European law (see also "The Impact of iConsumer Rights on the Legislative Process" section above). Both the national courts and the European Court of Justice (ECJ) play a part in the enforcement of fundamental rights through European legislation. The domestic courts have to make sure that the Directives concerning consumer contracts are given due effect. Moreover, they have to make sure that measures of national consumer law do not set unjustifiable restrictions to EC freedoms, such as - insofar as information services are concernedfreedom to provide goods and services. In case of doubts regarding the interpretation of EU law, the European Court of Justice (ECJ) should be consulted through the preliminary rulings procedure (Art. 35 EU Treaty jo. Art. 234 EC Treaty). As said earlier, the ECHR is of special relevance here:

"[W]here national rules fall within the scope of Community law and reference is made to it for a preliminary ruling, it must provide all criteria of interpretation needed by the national court to determine whether those rules are compatible with the fundamental rights the observance of which the Court ensures and which derive in particular from the ECHR."20

\footnotetext{
${ }^{19}$ Note that with regard to English law, this statement also rings true for situations that have been regulated in case law rather than in statutory provisions. Given the rule of precedent, judges cannot lightly deviate from rules established in earlier case law of a court which is higher in the court hierarchy, and the Court of Appeal in principle is bound by its own previous decisions. Fundamental rights may give judges a means to solve cases for which no answer is available in previous case law or in which the compliance of the earlier rules with fundamental rights is put into question.

${ }^{20}$ Case 94/00 Roquette Frères SA v Directeur général de la concurrence, de la consommation et de la répression des fraudes [2002] ECR I-9011.
} 
Through the "compliance check" of the interpretation of consumer law Directives with ECHR-protected rights, the ECJ's policy choices can become clear. On this point, the ECJ's handling of fundamental rights argumentation bears similarity to the manner in which many national courts deal with this type of reasoning: The intermediary role of fundamental rights serves to indicate the rule-solutions available to the court, which represent choices for either a more autonomy-based or a relatively solidarity-based policy (Mak 2008, Chapter 4).

\section{Fundamental Rights in iConsumer Cases: An Example}

A recent example from the ECJ's case law may illustrate how fundamental rights (in this case: a right laid down in the international Convention on the Rights of the Child) affect the application of EU law in a dispute between companies offering iConsumer services. The ECJ's judgment of 14 February 2008 in the case of Dynamic Medien v. Avides Media concerned a dispute arising under Directive 2000/31/EC (e-commerce). ${ }^{21}$ Avides Media, a German company, made a business of selling video and audio media through the Internet. Avides Media imported DVDs and video cassettes of certain Japanese cartoons from the United Kingdom to Germany. While the British Board of Film Classification had rated these cartoons as "suitable only for 15 years and over," the cartoons had not been examined by any German authorities. Dynamic Medien, a German competitor of Avides Media, brought a claim against Avides, stating that "the German 'Law on the protection of young persons prohibits the sale by mail order of image storage media which have not been examined in Germany in accordance with that Law, and which do not bear an age-limit label corresponding to a classification decision from a higher regional authority or a national self-regulation body ('competent authority')" (ECJ judgment, no. 13). The ECJ was then presented with the question whether the principle of freedom of movement of goods (Art. 28 EC Treaty) precluded a provision of national law prohibiting the sale by mail order of storage media (DVDs, videos) that were not labelled as having been examined by a competent authority as to their suitability for young persons and, if so, whether such a prohibition were justified (Art. 30 EC Treaty) (no. 15). ${ }^{22}$

Although establishing that the German provisions constituted a measure having equivalent effect to quantitative restrictions within the meaning of Art. 28 EC Treaty, the ECJ reached the conclusion that the restriction could, in principle, be objectively justified (no. 52). The justification of the rules was based on the fact that they were designed to protect young people, which is an objective covered by the grounds of justification mentioned in Art. 30 EC Treaty as well as in Directive 2000/31: public morality and public policy (no. 36). This judgment was further motivated by references to Art. 17 of the Convention on the Rights of the Child (CRC), under which provision the States Parties take it upon them to ensure the child's access to information. While the CRC explicitly words a right to receive information, it also seeks to protect children from harmful materials: Art. 17 (e) of the CRC says that "States are to encourage the development of appropriate guidelines for the protection of the child from information and material injurious to his or her wellbeing" (no. 40).

\footnotetext{
${ }^{21}$ Dynamic Medien Vertriebs GmbH v. Avides Media AG, C-244/06, ECJ 14 February 2008.

22 Since Directive 2000/31 (e-commerce) does not govern the requirements applicable to goods as such, e.g., concerning the protection of young persons buying goods by mail order from an Internet store, the case had to be adjudicated on the basis of Articles 28 and 30 EC Treaty.
} 
In accordance with its Omega judgment, ${ }^{23}$ the ECJ further considered that Member States have a margin of discretion regarding the level of protection they provide. The German law at stake would be in compliance with the principles of subsidiarity and proportionality as long as the examination procedure was readily accessible, the procedure could be completed within a reasonable period, and a refusal could be challenged before the courts (no. 50). It was left to the national court to determine whether these conditions were fulfilled in the present case.

This case example demonstrates how fundamental rights can affect the adjudication of iConsumer contracts. It confirms the aforementioned theory of "mediation" of fundamental rights between contract law and public policy, since the application of the CRC colours the ECJ's interpretation of public morality. In effect, the Court's application of fundamental rights shows similarities with the aforementioned German theory of Wechselwirkung: a reciprocal effect between a general clause of private law (public morality and public policy) and a fundamental right (Art. $17 \mathrm{CRC}$ ).

From the perspective of harmonisation, a point of criticism of the ECJ's judgment concerns the Court's apparent reluctance to accept the need for a common notion of "public policy" in light of fundamental rights when a restriction of EC freedoms is questioned. In this context, it is remarkable that the ECJ has ruled quite differently in case law concerning the enforcement of EC law: insofar as Community law is concerned, prevalence in that case is given to the ECJ's interpretation of fundamental rights over the interpretation by a national Constitutional Court. ${ }^{24}$ It is not clear why the Court makes a distinction here, since both the restriction and the enforcement of Community law define the borderlines of EU competence in relation to national laws. It would therefore be desirable if some more consideration were given to the extent to which the ECJ can and should interfere with the interpretation of fundamental rights on the domestic level. If fundamental rights colour the interpretation of vague norms such as "public policy," then an overruling interpretation of the ECJ seems to imply that the Court can indirectly develop a uniform notion of this concept after all. This would affect all contracts governed by European law, including iConsumer contracts. Although this might further the harmonisation of contract law in Europe, such a development would at the same time create a tension with the principle of subsidiarity (Art. 5 EC Treaty). Hopefully, future case law of the ECJ will clarify this issue.

\section{Conclusion}

Survival of the fittest or protection of the weakest - policy choices in the field of European Consumer Law usually lie somewhere in the middle between these two extremes. In this paper, it has been examined how fundamental rights relate to the choices that the legislature

\footnotetext{
${ }^{23}$ Case 36/02 Omega Spielhallen- und Automatenaufstellungs-GmbH v. Oberbürgermeisterin der Bundesstadt Bonn [2004] OJ C 300, 3. The case concerned the prohibition of a "laserdrome" in Bonn, Germany, where people could "play at killing" each other. Since the laserdrome's equipment was purchased from a British company, the prohibition would allegedly constitute an unjustified restriction of the freedom to provide services (Art. 49 EC). In its judgment, the ECJ considered the restriction of obligations imposed by Community law on the basis of fundamental rights, in particular human dignity. The Court held that "[i]t is not indispensable in that respect for the restrictive measure issued by the authorities of a Member State to correspond to a conception shared by all Member States as regards the precise way in which the fundamental right or legitimate interest in question is to be protected."

${ }^{24}$ Cordero Alonso v. Fogasa, C-81/05, ECJ 7 September 2006. A case note to this judgment by the author of the present article has been published in (2007) European Review of Contract Law, 432-438.
} 
and the judiciary have to make between aims of autonomy-based policy and objectives of social justice. In particular, attention has been paid to contracts regarding digital information services, a market branch that is rapidly expanding and-as the European Commission affirms - is in need of regulation. To what extent should the consumer of copyright protected content, the iConsumer, be protected?

Since all parties to iConsumer contracts, viz. the consumer, the author, and the supplier, hold fundamental rights, a balance of interests has to be struck. A brief look into the European legislature's review of the acquis communautaire has shown that the policy choices made in the process of this revision relate to the outcome of this balancing process: an emphasis on consumer rights will, for instance, result in an expansion of the scope of application of the Consumer Sales and Distance Selling Directives, whereas a focus on copyright holder's rights points in the opposite direction. Similar policy issues arise in the application of European Consumer Law in the case law of the European Courts. The example of the Dynamic Medien v. Avides Media judgment has clarified how the ECJ takes into account fundamental rights when evaluating the possible restriction of free movement of services in light of considerations of public policy. A proportionality test then again requires for the interests of the various parties to be weighed.

Legislation and adjudication on iConsumer contracts thus require a careful assessment of the policy issues at stake. Fundamental rights can help the legislature and judiciary define these issues in questions concerning iConsumer contracts. Although this does not immediately provide a "right answer" to the questions concerned, it raises awareness of the interests that are pursued by consumer organisations and businesses through European (Consumer) Contract Law. Striking the balance between these interests then means making a choice for either a more autonomy-based or a more protective policy. Fundamental rights argumentation shows that this task does not exclusively involve the legislature, but also regards the judiciary. In line with the Commission's aim to enhance the coherence of European Contract Law, further thought should therefore be given to the role of the European courts, in particular the ECJ, in the uniform interpretation of (iConsumer and consumer) contract law rules in light of fundamental rights.

Open Access This article is distributed under the terms of the Creative Commons Attribution Noncommercial License which permits any noncommercial use, distribution, and reproduction in any medium, provided the original author(s) and source are credited.

\section{References}

Bamforth, N. (2001). The true "horizontal effect" of the Human Rights Act 1998. Law Quarterly Review, 117,34 .

Barak, A. (2001). Constitutional human rights and private law. In D. Friedmann, \& D. Barak-Erez (Eds.), Human rights in private law (pp. 13-42). Oxford: Hart Publishing.

Beale, H., \& Pittam, N. (2001). The impact of the Human Rights Act 1998 on English tort and contract law. In D. Friedmann, \& D. Barak-Erez (Eds.), Human rights in private law (pp. 131-159). Oxford: Hart Publishing.

Beatson, J., \& Grosz, S. (2000). The impact of the Human Rights Act on private law: the knight's move. Law Quarterly Review, 116, 380.

Brüggemeier, G., Colombi Ciacchi, A., \& Comandé, G. (eds.) (2009a). Fundamental rights and private law in the European Union. I. A comparative overview. Cambridge: Cambridge University Press, (in press). 
Brüggemeier, G., Colombi Ciacchi, A., \& Comandé, G. (eds.) (2009b). Fundamental rights and private law in the European Union. II. Comparative analyses of selected case patterns. Cambridge: Cambridge University Press, (in press).

Busnelli, F. D. (1991). Diritti umani e civiltà giuridica. Riflessioni di un civilista. Rassegna di diritto civile, 243-254.

Buxton, R. (2000). The Human Rights Act and private law. Law Quarterly Review, 116, 48.

Chiarella, M. L. (2004). La tutela dei diritti fondamentali nei rapporti interprivati: elaborazioni teoriche e stato dell'arte. In G. Comandé (Ed.), Diritto privato europeo e diritti fondamentali (pp. 39-74). Torino: G. Giappichelli Editore.

Collins, H. (2007). Utility and rights in common law reasoning: Rebalancing private law through constitutionalization. Dalhousie Law Journal, 30, 1-26.

Colombi Ciacchi, A. (2006). The constitutionalization of European contract law. Judicial convergence and social justice. European Review of Contract Law, 167-180.

Commission (2001). Communication on European Contract Law to the Council and the European Parliament, 11 July 2001, COM (2001) 398 final.

Commission (2003). A more coherent European contract law. An action plan. Communication to the European Parliament and the Council, 12 February 2003, COM (2003) 68 final.

Commission (2004). European contract law and the revision of the acquis: The way forward. Communication to the European Parliament and the Council, 11 October 2004, COM (2004) 651 final.

Commission (2006). Green paper on the review of the consumer acquis, 8 February 2007, COM (2006) 744 final.

Commission Report on the outcome of the public consultation on the green paper on the review of the consumer acquis (2007). <http://ec.europa.eu/consumers/cons int/safe shop/acquis/acquis working doc.pdf $>$ (last consulted on 11 June 2008)

Commission Proposal (2008), Proposal for a directive of the European Parliament and of the Council on consumer rights, COM (2008) 614/3.

Cooper, J. (2000). Horizontality: The application of human rights standards in private disputes. In R. English, \& P. Havers (Eds.), An introduction to human rights and the common law (p. 53). Oxford: Hart Publishing.

Dworkin, R. (1977). Taking rights seriously. London: Duckworth (fourth impression with a Reply to critics, London: Duckworth, 1984).

Gerstenberg, O. (2004). Private law and the new European constitutional settlement. European Law Journal, 766-786.

Helberger, N., \& Hugenholtz, P. B. (2007). No place like home for making a copy: Private copying in European copyright law and consumer law. Berkeley Technology Law Journal, 22, 1061-1098.

Hesselink, M. W. (2001). The Principles of European Contract Law: Some choices made by the Lando Commission. In Principles of European Contract Law (preliminary reports Vereniging voor Burgerlijk Recht). Deventer: Kluwer, 7-103.

Hesselink, M. W. (ed.) (2006). The politics of a European Civil Code. The Hague: Kluwer Law International. Hunt, M. (1998). The "horizontal effect" of the Human Rights Act. Public Law, 422.

Kennedy, D. (1976). Form and substance in private law adjudication. Harvard Law Review, 89, $1685-1778$.

Kennedy, D. (1997). A critique of adjudication \{fin de siècle\}. Cambridge, Massachusetts: Harvard University Press.

Kennedy, D. (2002). The political stakes in "merely technical" issues of contract law. European Review of Private Law, 7-28.

Loos, M. B. M. (2008). Review of the European consumer acquis. München: Sellier, European Law Publishers. Also available as a working paper of the Centre for the Study of European Contract Law on $<$ http://www.jur.uva.nl/csecl>

Mak, C. (2007). Harmonising effects of fundamental rights in European contract law. Erasmus Law Review, 59-79. <http://www.erasmuslawreview.nl/past_issues/Volume01/harmonising_effects>

Mak, C. (2008). Fundamental rights in European contract law. A comparison of the impact of fundamental rights on contractual relationships in Germany, the Netherlands, Italy and England. Alphen aan den Rijn: Kluwer Law International.

Morelli, S. (1996). L'applicazione diretta della Costituzione nei rapporti interindividuali, Giustizia civile, 537-548.

Morgan, J. (2004). Privacy in the House of Lords, again. Law Quarterly Review, 120, 564.

Phillipson, G. (1999). The Human Rights Act, "horizontal effect" and the common law: a bang or a whimper? Modern Law Review, 62, 824.

Phillipson, G. (2003a). Judicial reasoning in breach of confidence cases under the Human Rights Act: Not taking privacy seriously. European Human Rights Law Review, 8, Special issue on privacy, 54. 
Phillipson, G. (2003b). Transforming breach of confidence? Towards a common law right of privacy under the Human Rights Act. Modern Law Review, 66, 726.

Smits, J. M. (2003). Constitutionalisering van het vermogensrecht. In Preadviezen uitgebracht voor de Nederlandse Vereniging voor Rechtsvergelijking 2003. Deventer: Kluwer, 1-163.

Social Justice Group (2004). Social justice in European contract law: A manifesto. European Law Journal, $653-674$.

Taylor, G. (2002). The horizontal effect of human rights provisions, the German model and its applicability to common-law jurisdictions. King's College Law Journal, 13, 187.

Wade, W. (1998). The United Kingdom's Bill of Rights. In J. Beatson, C. Forsyth, \& I. Hare (Eds.), Constitutional reform in the United Kingdom: Practice and principles (p. 61). Oxford: Hart Publishing.

Wade, H. W. R. (2000). Horizons of horizontality. Law Quarterly Review, 116, 217.

Wadham, J., et al. (2007). Blackstone's guide to the Human Rights Act 1998. Oxford: Oxford University Press.

Van Zelst, B. (2008). The politics of sales law. A legal-political inquiry into the drafting of the Uniform Commercial Code, the Vienna Sales Convention, the Dutch Civil Code and the European Consumer Sales Directive in the context of the Europeanisation of contract law. Alphen aan den Rijn: Kluwer Law International. 